\title{
Analysis of factors associated with early neonatal deaths through linkage between SIM and SINASC, in Sergipe, Brazil
}

Análise dos fatores associados aos óbitos neonatais precoces através de linkage entre SIM e SINASC, em Sergipe, Brasil

Análisis de los factores asociados a las muertes neonatales tempranas a través de la vinculación entre SIM y SINASC, en Sergipe, Brasil

\author{
Thais Serafim Leite de Barros Silva \\ ORCID: https://orcid.org/0000-0003-1696-6507 \\ Universidade Federal de Sergipe, Brazil \\ E-mail: thaisserafim@ hotmail.com \\ Sérgio de Brito Barbosa \\ ORCID: https://orcid.org/0000-0003-1024-5856 \\ Universidade Federal de Sergipe, Brazil \\ E-mail: sergiobbrito@hotmail.com \\ Lara Benario de Lisboa Santos \\ ORCID: https://orcid.org/0000-0001-5195-2499 \\ Universidade Federal de Sergipe, Brazil \\ E-mail: lara_benario@hotmail.com \\ Rayssa da Nóbrega Didou \\ ORCID: https://orcid.org/0000-0001-9429-2240 \\ Universidade Federal de Sergipe, Brazil \\ E-mail: rayssa.didou@gmail.com \\ Júlia Maria Gonçalves Dias \\ ORCID: https://orcid.org/0000-0001-9145-5534 \\ Universidade Federal de Sergipe, Brazil \\ E-mail: dias_jmg@yahoo.com.br \\ Vinícius da Silva Martins \\ ORCID: https://orcid.org/0000-0002-6673-8003 \\ Universidade Federal de Sergipe, Brazil \\ E-mail: martinsvinicius51@gmail.com \\ João Eduardo Andrade Tavares de Aguiar \\ ORCID: https://orcid.org/0000-0002-9576-8148 \\ Universidade Federal de Sergipe, Brazil \\ E-mail: joaoeduardoandrade97@ gmail.com \\ Marco Antônio Prado Nunes \\ ORCID: https://orcid.org/0000-0001-5244-5843 \\ Universidade Federal de Sergipe, Brazil \\ E-mail: nunes.ma@ufs.br
}

\begin{abstract}
In Brazil, more than $70 \%$ of neonatal deaths are concentrated in the early neonatal period, with about $41.2 \%$ of them occurring in the first 24 hours of life. Thus, the objective of this study was to carry out an analysis of factors associated with early neonatal deaths that occurred in Sergipe, Brazil, through the linkage of records in the information systems: Live Birth Information System (SINASC) and Mortality Information System (SIM). This study was carried out in Sergipe, Brazil, in which an analysis was made of secondary data on children born and early neonatal deaths in Sergipe between 2006 and 2019 registered in the SINASC and in the SIM. A linkage was carried out between the databases, identifying 484,629 live births, 480,784 survivors and 3,845 who died with less than 7 days of life, with a low percentage of ignored data or absent. Maternal age was similar between groups. However, the newborns who died had lower weight, gestational age and Apgar in the first and fifth minutes than the survivor group. Regarding the newborn, there were more deaths in males and in congenital malformations. As for information about the mother and pregnancy, there were more deaths in single women, multiple pregnancies, lower gestational ages and vaginal delivery. There was an association between neonatal deaths and lower Apgar in the first and fifth minutes, lower weights, lower gestational ages, male gender, congenital malformations, women with multiple pregnancies, vaginal births and single mothers.
\end{abstract}

Keywords: Early neonatal mortality; Perinatal death; Health information systems. 


\begin{abstract}
Resumo
No Brasil, mais de $70 \%$ dos óbitos neonatais concentram-se no período neonatal precoce, com cerca de 41,2\% deles ocorrendo nas primeiras 24 horas de vida. Assim, o objetivo deste estudo foi realizar uma análise dos fatores associados aos óbitos neonatais precoces ocorridos em Sergipe, Brasil, por meio da vinculação dos registros nos sistemas de informação: Sistema de Informações sobre Nascidos Vivos (SINASC) e Informações sobre Mortalidade Sistema (SIM). Trata-se de um estudo realizado em Sergipe, Brasil, em que se analisou dados secundários de crianças nascidas e óbitos neonatais precoces em Sergipe entre 2006 e 2019 registrados no SINASC e no SIM. Foi realizado um linkage entre as bases de dados, identificando 484.629 nascidos vivos, 480.784 sobreviventes e 3.845 que faleceram com menos de 7 dias de vida, com baixo percentual de dados ignorados ou ausentes. A idade materna foi semelhante entre os grupos. No entanto, os recém-nascidos que morreram apresentavam peso, idade gestacional e Apgar no primeiro e quinto minutos menores do que o grupo sobrevivente. Em relação ao recém-nascido, ocorreram mais óbitos no sexo masculino e nas malformações congênitas. Quanto às informações sobre a mãe e a gravidez, ocorreram mais óbitos em mulheres solteiras, gravidez múltipla, menor idade gestacional e parto normal. Houve associação entre óbitos neonatais e menor Apgar no primeiro e quinto minutos, menores pesos, menores idades gestacionais, sexo masculino, malformações congênitas, mulheres com gravidez múltipla, partos vaginais e mães solteiras.
\end{abstract}

Palavras-chave: Mortalidade neonatal precoce; Morte perinatal; Sistemas de informação em saúde.

\title{
Resumen
}

En Brasil, más del 70\% de las muertes neonatales se concentran en el período neonatal temprano, y alrededor del 41,2\% ocurren en las primeras 24 horas de vida. Así, este estudio tuvo como objetivo realizar análisis de factores asociados a muertes neonatales tempranas ocurridas en Sergipe, Brasil, a través de la vinculación de registros en los sistemas de información: Sistema de Información de Nacidos Vivos (SINASC) y Información de Mortalidad Sistema (SIM). Se trata de un estudio realizado en Sergipe, Brasil, en el que se realizó un análisis de datos secundarios sobre niños nacidos y muertes neonatales tempranas en el Sergipe entre 2006 y 2019 registrados en el SINASC y en el SIM. Se realizó una vinculación entre las bases de datos, identificando 484.629 nacidos vivos, 480.784 supervivientes y 3.845 fallecidos con menos de 7 días de vida, con un bajo porcentaje de datos ignorados o ausentes. La edad materna fue similar entre los grupos. Sin embargo, los recién nacidos que fallecieron tuvieron menor peso, edad gestacional y Apgar en el primer y quinto minutos que el otro grupo. En cuanto al recién nacido, hubo más muertes en varones y en malformaciones congénitas. En cuanto a la información sobre la madre y el embarazo, hubo más muertes en solteras, embarazos múltiples, edades gestacionales más bajas y parto vaginal. Hubo asociación entre muertes neonatales y menor Apgar en el primer y quinto minuto, menor peso, menor edad gestacional, niños, malformaciones congénitas, mujeres con embarazos múltiples, partos vaginales y madres solteras.

Palabras clave: Mortalidad neonatal precoz; Muerte perinatal; Sistemas de información en salud.

\section{Introduction}

Infant mortality is a health priority in several international and national pacts, such as the Millennium Goals for the year 2015 and the Sustainable Development Goals for the year 2030. The infant mortality rate is internationally standardized and traditionally analyzed according to two components, which have different determinants in the population: neonatal mortality (deaths from 0 to 27 days of complete life) and post-neonatal mortality (28 days to 1 year) (França \& Lansky, 2008).

Although post-neonatal mortality has shown a significant reduction in recent decades, neonatal mortality had a slower reduction. This period is divided into an early ( 0 to 6 full days of life) and a late (7 to 27 full days of life) neonatal component. In Brazil, it is in the early component that more than $70 \%$ of neonatal deaths are concentrated, with about $41.2 \%$ of them occurring in the first 24 hours of life (Gaíva et al., 2013).

There are significant differences in neonatal deaths between non-developed and developed countries. Brazil, for example, presented, according to the United Nations (UN), a death rate for every 1000 live births, four times higher than Italy, in 2017 (Boas et al., 2021).

Furthermore, in countries with continental dimensions, such as Brazil, disparities also occur at the regional level. Comparatively, mortality in the first seven days of life had a decline of $42 \%$ in the Southeast region between 1997 and 2012 , while in the Northeast region the reduction was $23 \%$ in the same period. Such disparities reflect the socioeconomic conditions of each location (Rodrigues et al., 2016).

In addition to socioeconomic conditions, which directly influence the pregnant woman's reality of life, access to 
health, nutrition and education, several other aspects are related to infant deaths. Neonatal mortality is connected with biological conditions related to pregnancy and childbirth, as well as the baby's genetics, which include here the occurrence of congenital malformations (Nunes et al., 2021).

Among so many variables linked to early neonatal mortality, studies demonstrate the importance of carrying out retrospective investigations of deaths to establish causal links through data analysis. In this sense, the improvement of the Health Information Systems (SIS), in particular the Mortality Information System (SIM) and the Live Birth Information System (SINASC), added to the possibility of linking both banks, has contributed for better quality of information. Thus, it is possible to address early neonatal mortality and its determinants (Nunes et al., 2021; Silva, Leite \& Almeida, 2009).

Therefore, the objective of this study was to carry out an analysis of factors associated with early neonatal deaths that occurred in the state of Sergipe, Brazil, through the linkage of records in the information systems: SIM and SINASC.

\section{Methodology}

\subsection{Study design}

This study was based on secondary data from official databases and carried out in Sergipe, Brazil, in which an analysis was made of secondary data on children born in the state of Sergipe between 2006 and 2019 registered in the SINASC and in the SIM.

\subsection{Study location}

This study was carried out using data provided by the Information Systems (SI) of the Ministry of Health from Brazil.

\subsection{Target population}

The study population consisted of all live births registered in the SINASC and early neonatal deaths registered in the SIM, of residents in the state of Sergipe, in the period between 2006 and 2019.

\subsection{Inclusion and exclusion criteria}

In this research, all children of both sexes born in the aforementioned period registered in the SINASC were included. All children who died from zero to six full days of life in the SIM were identified. Those residing in municipalities outside the state of Sergipe were excluded.

\subsection{Analyzed variables}

Data were obtained by analyzing the live birth certificate and the newborn's death certificate. The variables analyzed were:

- MOTHERAGE: mother's age;

- APGAR1: Apgar in the first minute;

- APGAR5: Apgar in the fifth minute;

- WEIGHT: birth weight in grams;

- GESTWEEKS: number of weeks of gestation;

- SEX: sex (whether male, female or ignored);

- ANOMALYID: anomaly detected (if yes, no or ignored);

- PREGNANCY: type of pregnancy (if single, double, triple or more or ignored);

- DELIVERY: type of delivery (if vaginal, cesarean or ignored); 
- $\quad$ PREGNANCY: weeks of gestation (if minus 22 weeks, if 22 to 27 weeks, if 28 to 31 weeks, if 32 to 36 weeks, if 37 to 41 weeks, if 42 weeks and over, or if ignored);

- MARMOMSTAT: marital status of the mother (if single, married, widowed, separated/divorced, stable or ignored);

- MATERNALSCHOOLING: schooling, in years of schooling completed (if none, if 1 to 3 years, if 4 to 7 years, if 8 to 11 years, if 12 and over, or if ignored).

\subsection{Data analysis}

The deterministic linkage method was applied between SIM and SINASC. Deterministic matching is based on the selection of variables common to two or more different databases, with the aim of finding the same individual in the paired databases (Moody, 2017).

Initially, for this linkage, live births registered in SINASC, residents of Sergipe, from the cohort of live births, between 2006 and 2019, were selected. At the same time, early neonatal deaths registered in SIM, residents of Sergipe, between 2006 and 2019 were selected. Subsequently, variables common to both systems were selected and the information was paired, seeking to find the Live Birth Certificate corresponding to each death.

\subsection{Ethical aspects}

This research was planned in accordance with the Declaration of Helsinki and Resolution 466, of 2012, of the National Health Council. It was submitted to the Research Ethics Committee of UFS, with CAAE: 48189721.0.0000.5546.

\section{Results}

A linkage was carried out between the SIM and SINASC databases, between the years 2006 to 2019, identifying 484,629 live births, 480,784 survivors and 3,845 who died with less than 7 days of life, with a low percentage of ignored data or absent.

Descriptive analysis of the data showed similar average age of mothers in newborns who survived (25.7 years) and in early neonatal deaths (25.8 years) ( $\mathrm{p}>0.05)$. Regarding the average gestational age, a greater average of the gestational age was obtained in the neonates who survived $(\mathrm{GA}=38 \mathrm{~s})$ than in the deaths $(\mathrm{GI}=29 \mathrm{~s})(\mathrm{p}<0.05)$. The 1st minute Apgar score was lower in death (average 3.8) than in survivors (average 8.4) (p < 0.05). Similarly, the Apgar score at the 5th minute was lower in death (average 5.3) than in survivors (average 9.5). Birth weight had a lower average in deaths (average 1544.1) than in survivors (average 3242.3) $(\mathrm{p}<0.05)$ as shown in Table 1. 
Table 1. Descriptive analysis of the analyzed variables, respectively, mother, pregnancy, childbirth, and the newborn, for early neonatal mortality, in Sergipe, Brazil, 2006 to 2019, through a linkage between SIM and SINASC.

\begin{tabular}{|c|c|c|c|c|c|c|c|}
\hline & Death & Average & Standard Desviation & Median & IQR & p value & Present Data \\
\hline \multirow[t]{2}{*}{ MOTHERAGE } & No & 25.7 & 6.7 & 25.0 & 11.0 & \multirow{2}{*}{0.912} & $100 \%$ \\
\hline & Yes & 25.8 & 7.1 & 25.0 & 11.0 & & $100 \%$ \\
\hline \multirow[t]{2}{*}{ APGAR1 } & No & 8.4 & 1.3 & 9.0 & 1.0 & \multirow{2}{*}{$<0.001 *$} & $97 \%$ \\
\hline & Yes & 3.8 & 2.8 & 3.0 & 5.0 & & $91 \%$ \\
\hline \multirow[t]{2}{*}{ APGAR5 } & No & 9.5 & 0.9 & 10.0 & 1.0 & \multirow{2}{*}{$<0.001 *$} & $97 \%$ \\
\hline & Yes & 5.3 & 3.1 & 6.0 & 6.0 & & $92 \%$ \\
\hline \multirow[t]{2}{*}{ WEIGHT } & No & 3242.3 & 547.4 & 3260.0 & 635.0 & \multirow{2}{*}{$<0.001 *$} & $100 \%$ \\
\hline & Yes & 1544.1 & 1114.8 & 1119.0 & 1812.5 & & $100 \%$ \\
\hline \multirow[t]{2}{*}{ GESTWEEKS } & No & 38.7 & 2.0 & 39.0 & 2.0 & \multirow{2}{*}{$<0.001 *$} & $62 \%$ \\
\hline & Yes & 29.7 & 6.6 & 29.0 & 12.0 & & $61 \%$ \\
\hline
\end{tabular}

Source: Elaborated by the authors based on data from the Mortality Information System and the Live Birth Information System, Ministry of Health, Brazil.

Regarding the characteristics of the newborn, the number of neonatal deaths was proportionally higher in males $(0.9 \%)$ than in females $(0.7 \%)$ as well as in babies born with some type of congenital malformation (11.9\%). Both statistically relevant frequencies $(\mathrm{p}<0.05)$, as shown in Table 2 .

Table 2. Absolute and relative distribution of the analyzed variables related to newborns, for early neonatal mortality, in Sergipe, Brazil, 2006 to 2019, through the linkage between SIM and SINASC.

\begin{tabular}{|c|c|c|c|c|c|c|}
\hline & \multicolumn{4}{|c|}{ Death } & \multirow{3}{*}{ Total } & \multirow{3}{*}{ P Value } \\
\hline & \multicolumn{2}{|c|}{ Not } & \multicolumn{2}{|c|}{ Yes } & & \\
\hline & $\mathbf{N}$ & $\%$ & $\mathbf{N}$ & $\%$ & & \\
\hline \multicolumn{7}{|l|}{ SEX } \\
\hline Female & 234,656 & $99,3 \%$ & 1,599 & $0,7 \%$ & 236,255 & \multirow{3}{*}{$<0.001 *$} \\
\hline Male & 246,080 & $99,1 \%$ & 2,191 & $0,9 \%$ & 248,271 & \\
\hline Total & 480,736 & $100 \%$ & 3,790 & $100 \%$ & 484,526 & \\
\hline \multicolumn{7}{|c|}{ ANOMALYID } \\
\hline Yes & 4,273 & $88,1 \%$ & 574 & $11,9 \%$ & 4,847 & \multirow{3}{*}{$<0.001 *$} \\
\hline No & 472,665 & $99.3 \%$ & 3,197 & $0,7 \%$ & 475,862 & \\
\hline Total & 476,938 & $100 \%$ & 3,771 & $100 \%$ & 480,709 & \\
\hline
\end{tabular}

Source: Elaborated by the authors based on data from the Mortality Information System and the Live Birth Information System, Ministry of Health, Brazil.

In terms of childbirth characteristics, it was observed that there were proportions of higher early neonatal deaths at younger gestational ages, reaching $79.3 \%$ of deaths in pregnancies less than 22 weeks $(\mathrm{p}<0.05)$. Furthermore, the greater the number of children per pregnancy, the greater the mortality. In single pregnancies there was $0.7 \%$ of deaths, while in pairs there were $4.2 \%$ of deaths and in triples or more $9 \%$ of deaths $(\mathrm{p}<0.05)$. With regard to the type of delivery, a higher relative neonatal mortality was observed in vaginal deliveries $(0.9 \%)$ compared to cesarean deliveries $(0.6 \%)(\mathrm{p}<0.05)($ Table 3$)$. 
Table 3. Absolute and relative distribution of the analyzed variables related to childbirth, for early neonatal mortality, in Sergipe, Brazil, 2006 to 2019, through linkage between SIM and SINASC.

\begin{tabular}{|c|c|c|c|c|c|c|}
\hline & \multicolumn{4}{|c|}{ Death } & \multirow{3}{*}{ Total } & \multirow{3}{*}{$p$ value } \\
\hline & \multicolumn{2}{|c|}{ Not } & \multicolumn{2}{|c|}{ Yes } & & \\
\hline & n & $\%$ & $\mathbf{n}$ & $\%$ & & \\
\hline \multicolumn{7}{|l|}{ PREGNANCY } \\
\hline Single & 471,379 & $99,3 \%$ & 3,441 & $0,7 \%$ & 474,820 & \multirow{4}{*}{$<0.001 *$} \\
\hline Double & 8,788 & $95,8 \%$ & 383 & $4,2 \%$ & 9,171 & \\
\hline Triple or more & 194 & $91 \%$ & 19 & $9 \%$ & 213 & \\
\hline Total & 480,361 & $100 \%$ & 3,843 & $100 \%$ & 484,204 & \\
\hline \multicolumn{7}{|l|}{ DELIVERY } \\
\hline Cesarean & 185,227 & $99,3 \%$ & 1,187 & $0,6 \%$ & 186,414 & \multirow{3}{*}{$<0.001^{*}$} \\
\hline Vaginal & 295,161 & $99,1 \%$ & 2,657 & $0,9 \%$ & 297,818 & \\
\hline Total & 480,388 & $100 \%$ & 3,844 & $100 \%$ & 484,232 & \\
\hline \multicolumn{7}{|l|}{ GESTATION } \\
\hline less than 22 weeks & 103 & $20,7 \%$ & 394 & $79,3 \%$ & 497 & \multirow{7}{*}{$<0.001^{*}$} \\
\hline 22 to 27 weeks & 1,044 & $48 \%$ & 1,130 & $52 \%$ & 2,174 & \\
\hline 28 to 31 weeks & 3,189 & $84,5 \%$ & 583 & $15.5 \%$ & 3,772 & \\
\hline 32 to 36 weeks & 33,501 & $97,9 \%$ & 727 & $2,1 \%$ & 34,228 & \\
\hline 37 to 41 weeks & 429,304 & $99,8 \%$ & 890 & $0,2 \%$ & 430,194 & \\
\hline 42 weeks or more & 9,353 & $99,6 \%$ & 35 & $0.4 \%$ & 9,388 & \\
\hline Total & 476,494 & $100 \%$ & 3,759 & $100 \%$ & 480,253 & \\
\hline
\end{tabular}

Source: Elaborated by the authors based on data from the Mortality Information System and the Live Birth Information System, Ministry of Health, Brazil.

In relation to sociodemographic characteristics, of the 105,100 newborns of married mothers, $694(0.7 \%)$ died. Of the 254,010 children of single mothers, $2325(0.9 \%)$ had a fatal outcome ( $<<0.05)$. In turn, in relation to the mother's level of education, the proportion was similar regardless of the number of years of education, ranging from 0.8 to $0.9 \%$ of deaths per category (Table 4). 
Table 4. Absolute and relative distribution of the analyzed variables related to the sociodemographic characteristics of the mother, for early neonatal mortality, in Sergipe, Brazil, 2006 to 2019, through a linkage between SIM and SINASC.

\begin{tabular}{|c|c|c|c|c|c|c|}
\hline & \multicolumn{4}{|c|}{ Death } & \multirow{3}{*}{ Total } & \multirow{3}{*}{$p$ value } \\
\hline & \multicolumn{2}{|c|}{ Not } & \multicolumn{2}{|c|}{ Yes } & & \\
\hline & $\mathbf{n}$ & $\%$ & $\mathbf{n}$ & $\%$ & & \\
\hline \multicolumn{7}{|l|}{ MARMOMSTAT } \\
\hline Married & 104,406 & $99,3 \%$ & 694 & $0,7 \%$ & 105,100 & \\
\hline Stable union & 115,231 & $99,4 \%$ & 740 & $0,6 \%$ & 115,971 & \\
\hline Single & 251,685 & $99,1 \%$ & 2,325 & $0,9 \%$ & 254,010 & $<0.001 *$ \\
\hline Legally separated/divorced & 2,667 & $98,8 \%$ & 31 & $1,2 \%$ & 2,698 & \\
\hline Widow & 782 & $99,1 \%$ & 7 & $0,9 \%$ & 789 & \\
\hline Total & 474,771 & $100 \%$ & 3,797 & $100 \%$ & 478,568 & \\
\hline \multicolumn{7}{|l|}{ MATERNALSCHOOLING } \\
\hline None & 8,481 & $99,1 \%$ & 78 & $0,9 \%$ & 8,559 & \\
\hline 1 to 3 years & 45,151 & $99,2 \%$ & 360 & $0,8 \%$ & 45,511 & \\
\hline 4 to 7 years & 147,505 & $99,2 \%$ & 1,144 & $0,8 \%$ & 148,649 & $0.276^{*}$ \\
\hline 8 to 11 years & 212,783 & $99,2 \%$ & 1,753 & $0,8 \%$ & 214,536 & \\
\hline 12 or more & 62,829 & $99,2 \%$ & 480 & $0,8 \%$ & 63,309 & \\
\hline Total & 476,749 & $100 \%$ & 3,815 & $100 \%$ & 480,564 & \\
\hline
\end{tabular}

Source: Elaborated by the authors based on data from the Mortality Information System and the Live Birth Information System, Ministry of Health, Brazil.

\section{Discussion}

The variables analyzed in the study were divided into intrinsic characteristics of the newborn, childbirth and sociodemographic characteristics. Through the statistical analysis performed, it was possible to identify which of them may be related to neonatal mortality.

There was a higher frequency of Apgar in the first and Apgar in the fifth minute lower in neonates who came to death. This score reflects the conditions of the NB in the first moments of life, being a reflection of other variables related to pregnancy and childbirth. A Swedish study published in The New England Journal of Medicine found that lower Apgar scores were associated with higher relative risks of neonatal mortality across all gestational age groups (Cnattingius et al., 2020).

Delivery characteristics such as low birth weight and gestational age below 28 weeks showed a higher frequency of early neonatal deaths in the present analysis. A case-control study on the determinants of infant mortality in 27 Brazilian capitals observed that low birth weight and prematurity are risk factors. Low birth weight represented the single factor with the greatest influence on the health and survival of the newborn, with a close relationship with prematurity. These two factors are greatly influenced by the quality of service provided during pregnancy (Maia et al., 2020).

Regarding the intrinsic characteristics of the NB, the male gender variable had a higher proportion of early neonatal deaths compared to females. Studies have shown higher neonatal mortality in males, however little is known about the reasons that are associated with this phenomenon. Some studies attribute this difference to late pulmonary maturation in this group, which would result in a higher incidence of respiratory pathologies and a higher frequency of hospitalizations (Alves \& Coelho, 2021; Nascimento et al., 2012).

The presence of congenital malformations was associated with higher proportions of early neonatal deaths in the present study, being a variable often determined as an independent risk factor for neonatal mortality. Analytical cross-sectional 
study that used data from 765 children in a Brazilian city identified congenital malformation as the second most frequent cause of neonatal death, second only to perinatal conditions. It is believed that primary prevention measures, such as reducing extreme maternal age, adequately vaccinating pregnant women, inspecting abortive medications and combating drug use during pregnancy could prevent more than half of the cases of congenital malformations (Carmo et al., 2021).

The higher proportion of vaginal deliveries compared to cesarean sections in early neonatal deaths is highlighted. A retrospective cohort study, in addition to bringing low birth weight and prematurity as factors with a higher odds ratio for the fatal outcome, brought cesarean section as a protective factor. It is suggested that the supervision of the obstetrician in the operating room is associated with lower risks of complications related to vaginal delivery, such as dystocia, meconium, and infectious complications (Saloio et al., 2020). However, studies alert to the complications inherent to cesarean delivery, such as surgical wound infections and the need for admission to the intensive care unit, highlighting the need for consideration in the choice of surgical delivery (Araújo et al., 2020).

In the study, a greater frequency of deaths was identified the greater the number of fetuses. It is known that twins have been associated with neonatal deaths. Singletons have a lower risk of dying when compared to twins. Newborns of twin pregnancies have a high incidence of low birth weight and prematurity at birth. Furthermore, twin pregnancies are more prone to complications such as preeclampsia, polyhydramnios, placental abruption, anemia, prolapse and circular cord (Sanders et al., 2020).

As for marital status, mothers who had partners, whether married or in a stable relationship, had a lower proportion of early neonatal deaths than mothers who were single, legally separated/divorced or widowed. This finding is in agreement with a study by Maia et al, (2012), in which being a mother who lived without a partner represented a risk factor for infant mortality.

Regarding maternal education, all age groups of study showed similar relative frequencies of neonatal deaths and there was no statistical association. However, studies carried out in southern Brazil have shown that low maternal education is related to infant mortality (Mombelli et al., 2012). A feasible explanation is that a better educational level may be associated with the correct follow-up of medical recommendations during pregnancy and soon after birth and the greater importance of home hygiene and cleaning habits related to newborns (Sanders et al., 2020).

\section{Conclusion}

There was an association between neonatal deaths and lower Apgar in the first and fifth minutes, lower weights, lower gestational ages, male gender, congenital malformations, women with multiple pregnancies, vaginal births and single mothers.

Therefore, conducting a linkage between databases of live births and neonatal deaths proves to be practicable and may enable actions to prevent risk factors associated with neonatal mortality.

New studies on linkage between the SIM and SINASC databases could be carried out in other states from Brazil and thus the financial resources could be applied in regions with the worst indicators related to early neonatal death.

\section{References}

Alves, T. F. \& Coelho, A. B. (2021). Mortalidade infantil e gênero no Brasil: uma investigação usando dados em painel. Ciência \& Saúde Coletiva, 26(4), 1259-1264. https://doi.org/10.1590/1413-81232021264.04022019

Araújo, L. A. M., Bezerra, I. N. M., Lima, J. C. S., Nascimento, J. L., Farias, L. L. S., Assis, L. T. D., Cardoso, G. R., Lins, D. J. P. \& Lima, M. W. H. (2020). Perfil da mortalidade neonatal no Rio Grande do Norte (2008-2017). Avances em Enfermería, 38(3). https://doi.org/10.15446/av.enferm.v38n3.84594

Boas, L. N. V., Lindenberg, C. D., Machado, D. F. S. C., Caetano, G. L., Carvalho, G. R., Bellario, L. C., Silva, S. Z. B., Matheus, T. H., Pinto, S. L. \& Pinheiro, Y. M. (2021). Óbito neonatal precoce e tardio: perfil das mães e recém-nascidos no estado de Rondônia. Revista Eletrônica Acervo Saúde, 13(8). https://doi.org/10.25248/reas.e8356.2021 
Carmo, L. B. V., Neves, L. F. C., Barrueco, M. C., Colombo, R. R., Sousa, R. T., Nezu, V. K. \& Donadel, L. L. V. (2021). Malformações congênitas e mortalidade infantil: análise transversal descritiva. COORTE-Revista Científica do Hospital Santa Rosa, 12. https://doi.org/10.52908/coorte.v0i12.187

Cnattingius, S., Johansson, S. \& Razaz N. (2020). Apgar score and risk of neonatal death among preterm infants. The New England Journal of Medicine, 383(1), 49-57. https://doi.org/10.1056/NEJMoa1915075

França, E. \& Lansky, S. (2008). Mortalidade infantil neonatal no Brasil: situação, tendências e perspectivas. Anais do XVI Encontro Nacional de Estudos Populacionais, 2008. http://www.abep.org.br/publicacoes/index.php/anais/issue/view/36/showToc

Gaíva, M. A. M., Bittencourt, R. M. \& Fujimori, E. (2013). Óbito neonatal precoce e tardio: perfil das mães e dos recém-nascidos. Revista Gaúcha de Enfermagem, 34(4), 91-97. https://doi.org/10.1590/S1983-14472013000400012

Maia, L. T. S., Souza, W. V. \& Mendes, A. C. G. (2012). Diferenciais nos fatores de risco para a mortalidade infantil em cinco cidades brasileiras: um estudo de caso-controle com base no SIM e no SINASC. Cadernos de Saúde Pública, 28(11), 2163-2176. https://doi.org/10.1590/S0102-311X2012001100016

Maia, L. T. S., Souza, W. V. \& Mendes, A. C. G. (2020). Determinantes individuais e contextuais associados à mortalidade infantil nas capitais brasileiras: uma abordagem multinível. Cadernos de Saúde Pública, 36(2). https://doi.org/10.1590/0102-311X00057519

Mombelli, M. A., Sass, A., Molena, C. A. F., Téston, E. F. \& Marcon, S. S. (2012). Fatores de risco para mortalidade infantil em município do Estado do Paraná, de 1997 a 2008. Revista Paulista de Pediatria, 30(2), 187-194. https://doi.org/10.1590/S0103-05822012000200006

Nascimento, R. M., Leite, A. J. M., Almeida, N. M. G. S., Almeida, P. C. \& Silva, C. F. (2012). Determinantes da mortalidade neonatal: estudo caso-controle em Fortaleza, Ceará, Brasil. Cadernos de Saúde Pública, 28(3), 559-572. https://doi.org/10.1590/S0102-311X2012000300016

Moody, J. (2017). Data integration manual. (2a ed.). Wellington.

Nunes, M. R. A., Sousa, L. V. A. \& Nascimento, V. B. (2021). Mortalidade infantil na Região Metropolitana de São Paulo: estudo ecológico. Einstein (São Paulo), 19, 1-7. http://dx.doi.org/10.31744/einstein_journal/2021AO5663

Rodrigues, N. C. P., Monteiro, D. L. M., Almeida, A. S., Barros, M. B. L., Pereira Neto, A., O’Dwyer, G., Andrade, M. K. N., Flynn, M. B. \& Lino, V. T. S. (2016). Temporal and spatial evolution of maternal and neonatal mortality rates in Brazil, 1997-2012. Jornal de Pediatria, 92(6), 567-573. https://doi.org/10.1016/j.jped.2016.03.004

Saloio, C. A., Morais Neto, O. L., Gonçalves, D. A., Bessa, H. E. M., Coelho Júnior, J. P., Afonso, M. S. M. \& Carvalho, S. R. (2020). Magnitude e determinantes da mortalidade neonatal e pós-neonatal em Goiânia, Goiás: um estudo de coorte retrospectivo, 2012. Epidemiologia e Serviços de Saúde, 29(5). https://doi.org/10.1590/S1679-49742020000500008

Sanders, L. S. C., Pinto, F. J. M., Sampaio, R., Viana, R. A. A., Lima, K. J. \& Maia, A. M. P. C. (2020). Perfil epidemiológico das mães e crianças constantes nas declarações de nascidos vivos e nas declarações de óbito. Revista de APS, 23(1). https://doi.org/10.34019/1809-8363.2020.v23.16055

Silva, C. F., Leite, A. J. M. \& Almeida, N. M. G. S. (2009). Linkage between live birth and infant death records in a municipality in Northeast Brazil: quality of the information system. Cadernos de Saúde Pública, 25(7), 1552-1558. https://doi.org/10.1590/S0102-311X2009000700013 